\title{
Nanosilica synthesis and application for lead treatment in water
}

\author{
Nghiên cứu tổng hợp nanosilica và ưng dụng xủ lí kim loại chì trong nước \\ Research article
}

Nguyen Xuan Huan*, Tran Nam Anh, Nguyen Thi Thuy Hang, Dao Thi Tuyet Nhung, Nguyen Van Thanh

Faculty of Environmental Sciences, VNU University of Science, Vietnam National University, Ha Noi, Vietnam

\begin{abstract}
Lead is a naturally occurring element that has high atomic weight $(207 \mathrm{u})$ and density $\left(11.3 \mathrm{~g} / \mathrm{cm}^{3}\right)$. Their multiple industrial, domestic, agricultural, medical and technological applications have led to their wide distribution in the environment, raising concerns over their potential effects on human health and the environment. At present, extensive application of nanosilica in environmental pollution treatment has led to the development of silica extraction methodologies out of various chemical and waste products. In this study, nanosilica is synthesized by sol-gel method from tetraethoxysilane (TEOS) with base catalysts and volumetric ratio TEOS $/ \mathrm{C}_{2} \mathrm{H}_{5} \mathrm{OH} / \mathrm{H}_{2} \mathrm{O} / \mathrm{NH}_{4} \mathrm{OH}$ : 5/30/1/1 and identified characteristics by some modern techniques such as Energy-dispersive $\mathrm{X}$ ray spectroscopy (EDX), Fourrier Transformation Infrared (FTIR) and X-ray diffraction (XRD), Scanning electron micrograph (SEM), field emission scanning electron microscopy (FESEM). The results showed that the prepared $\mathrm{SiO}_{2}$ nanoparticles were amorphous phase with the average size about 60-100 nm and can be used as an immediately utilization for lead treatment. At the $\mathrm{pH}$ of 5, shaking within 1 hours with speed $150 \mathrm{rpm} / \mathrm{min}$, lead treatment efficiency is $96.17 \%$ for initial $\mathrm{Pb}^{2+}$ concentration $10 \mathrm{mgPb}^{2+} / \mathrm{L}$. Maximum adsorption concentration $\mathrm{Qmax}=30.3 \mathrm{mg} / \mathrm{g}$, and adsorbent and adsorbate constant $b=0.868 \mathrm{~L} / \mathrm{g}$. Therefore, extracted nanosilica from TEOS has high lead treatment efficiency. In addition, synthesis nanosilica from rice husk with similar characteristics is a new research approach to improve application and economic value of the material.
\end{abstract}

Chì là nguyên tố tư nhiên có khối luợng nguyên tư cao(207 dvC), tỉ trong lớn $\left(11,3 \mathrm{~g} / \mathrm{cm}^{3}\right)$ và được ứng dụng phổ biến trong công nghiệp, nông nghiệp, sinh hoạt, y tế và công nghệ. Việc sử dụng rộng rãi chì trong nhiều lĩnh vưc làm tăng mối quan ngại về tác động tiềm tàng của chúng đối tới sức khỏe con nguời và môi truờng. Hiện nay việc áp dụng rộng rãa nanosilica vào xủ lí ô nhiếm môi truờng đã và đang dẫn đến sư phát triển của các phương pháp tách chiết silica tù hóa chất và các phế phu phẩm. Trong nghiên cứu này, nanosilica được tổng hợp bằng phuơng pháp sol-gel tù tetraetoxysilan (TEOS) với xúc tác bazo theo tỷ lẹ thể tích TEOS/ $\mathrm{C}_{2} \mathrm{H}_{5} \mathrm{OH} / \mathrm{H}_{2} \mathrm{O} / \mathrm{NH}_{4} \mathrm{OH}$ là $5 / 30 / 1 / 1$ và xác định các đặc tính bằng một số kỹ thuật hiện đại nhu phổ tán sắc năng luợng tia X (EDX), quang phổ hồng ngoại (FTIR) và nhiễu xạ tia X (XRD), kính hiển vi điện tư quét (SEM), kính hiến vi điện tư quét phát xa truờng (FESEM). Kết quả cho thấy các hạt nano $\mathrm{SiO}_{2}$ tách chiết được có pha vô định hinh với kích thuớc trung binh khoảng 60-100 nm và đuợc sủ dụng trục tiếp cho xủ̉ lí chì. Tai điều kiện $p H=5$, lắc trong 1 giờ với tốc độ 150 vòng/phút, hiệu quả xủ lý chì đạt 96,17\% đối với nước nhiếm kim loại chì có nồng độ ban đầu là $10 \mathrm{mgPb}{ }^{2+} /$ L. Luợng hấp phu cưc đại Qmax $=30,3 \mathrm{mg} / \mathrm{g}$; hằng số đặc trung của chất hấp phu và chất bị hấp phu $b=0,868 \mathrm{~L} / \mathrm{g}$. Nhu vậy, hiệu quả xủ lý kim loại chì của vật liệu nano silica được tổng hợp tù TEOS là rất cao. Bên cạnh đó, nghiên cưu chế tạo nanosilica tù vỏ trấu với các đặc tính tương tư là một huớng đi mói giúp nâng cao tính ứng dụng và giá trị kinh tế của vật liệu.

Keywords: characteristic, efficiency, lead, nanosilica, rice husk, sol-gel method, TEOS 


\section{Introduction}

In recent years, heavy metal has been an increasing ecological and global public health concern associated with aqueous environment. Lead is a significant element metal that contaminated the water by both natural and anthropogenic activities. It occurs naturally in the environment as natural weathering of the earth's crust. In addition, soil erosion and anthropogenic activities such as fossil fuels burning, mining, and manufacturing contribute to the release of its high concentrations.

Lead is chemical element which has been applied for many different industrial, agricultural and domestic activities. Exposure to lead occurs mainly via inhalation of lead-contaminated dust particles, ingestion of leadcontaminated food, and water. In the human body, the greatest percentage of lead is taken into the kidney, followed by the liver and the other soft tissues such as heart and brain. The nervous system is the most vulnerable target of lead poisoning. Headache, poor attention spam, irritability, loss of memory and dullness are the early symptoms of the effects of lead exposure on the central nervous system. Lead polluted are dangerous to health and to the environment, therefore, it is necessary to remove them from the polluted water.

A wide range of methods including chemical precipitation, solvent extraction, vacuum evaporation, membrane technologies, adsorption, ion exchange and membrane separation have been used to treat lead pollution environment (Ilka Gehrke et al. 2015 and Paul B Tchounwou et al. 2014). Using nanomaterials, for example, nanosilica is considered as new researching direction to treat lead pollution (Rahele Rostamian et al. 2011 and Rajesh Ghosh and Sounak Bhattacherjee. 2013). Nanosilica can be extracted from chemical or natural materials. Nanosilica was produced by various techniques including Stobër technique (Gholami, Salavati-Niasari et al. 2013), sol-gel methods (Le et al. 2013), and water-in-oil nanoemulsion system (Park, Ho et al. 2003). However, few studies have been carried out using slow gelation technique and freezedrying methods (Lu and Hsieh 2012).

In this study, nanosilica is synthesized by sol- gel method from TEOS and rice husk. This materials were characterized using Energy-dispersive X-ray spectroscopy (EDX), Fourrier Transformation Infrared (FTIR) and X-ray diffraction (XRD), Scanning electron micrograph (SEM), Field emission scanning electron microscopy (FESEM). In other aim of this study is to investigate the nanosilica capacity to treat lead in different conditions such as time, $\mathrm{pH}, \mathrm{Pb}^{2+}$ concentration and nanosilica concentration.

\section{Materials and methods}

\subsection{Materials}

The chemicals used consist of tetraethoxysilane (TEOS, $\geq 98 \%$, Merck), lead nitrate $\left(\mathrm{Pb}\left(\mathrm{NO}_{3}\right)_{2}, \geq 99.5 \%\right.$, Merck) as a lead source, ammonia solution (25\%, Scharlau), ethanol $\left(\mathrm{C}_{2} \mathrm{H}_{5} \mathrm{OH}\right)(99.7 \%$, China), hydrochloric acid $(\mathrm{HCl}, 37 \%$, China), sodium hydroxide $(\mathrm{NaOH}, \geq 96 \%$, China), and deionized water. And rice husk in the Red river delta was used as silica sources. Lead-contaminated water was manmade from $\mathrm{Pb}\left(\mathrm{NO}_{3}\right)_{2}$ to test the ability of the laboratory scale.

\subsection{Methods}

\subsubsection{Nanosilica synthesis method from TEOS}

Nanosilica is synthesized by sol gel method from TEOS with base catalysts and volumetric ratio TEOS $/ \mathrm{C}_{2} \mathrm{H}_{5} \mathrm{OH} / \mathrm{H}_{2} \mathrm{O} / \mathrm{NH}_{4} \mathrm{OH}: 5 / 30 / 1 / 1$. Precipitation of silica- chemical reaction involved:

$$
\begin{aligned}
\mathrm{Si}\left(\mathrm{OC}_{2} \mathrm{H}_{5}\right)_{4}+4 \mathrm{H}_{2} \mathrm{O} & \rightarrow \mathrm{Si}(\mathrm{OH})_{4}+4 \mathrm{C}_{2} \mathrm{H}_{5} \mathrm{OH} \\
\mathrm{Si}(\mathrm{OH})_{4} & \rightarrow \mathrm{SiO}_{2}+2 \mathrm{H}_{2} \mathrm{O}
\end{aligned}
$$

Taking exactly $50 \mathrm{~mL}$ TEOS into $300 \mathrm{~mL} \mathrm{C}_{2} \mathrm{H}_{5} \mathrm{OH}$ erlenmeyer flask. Stirring the solution in heating magnetic stirrer within 30 minutes. Adding gradually $10 \mathrm{~mL}$ deionized water and continuously stirring 30 minutes. Adding $10 \mathrm{~mL} \mathrm{NH}_{4} \mathrm{OH}(25 \%)$ to obtain the solution with $\mathrm{pH}$ of 8 and stirring to form sol (Enrique C. Peresa et al. 2018; Ezzat Rafieel et al. 2012 and Farshid Ghorbanil et al. 2015). After that, evaporating naturally within 48 hours. Putting the sol in oven at $80^{\circ} \mathrm{C}$ within 15 hours then crushing. Annealing at $450-550^{\circ} \mathrm{C}$ in 3 hours, and crushing again to obtain final product.

\subsubsection{Research on impact of time on $\mathrm{Pb}^{2+}$ treatment efficiency}

Taking $100 \mathrm{~mL}$ of $10 \mathrm{mg} / \mathrm{L} \mathrm{Pb}^{2+}$ solution into 5 erlenmeyer flasks $(250 \mathrm{~mL})$ and turning to $\mathrm{pH}=5$. Weighing and taking $0.1 \mathrm{~g}$ nanosilica into each flask, then shaking with speed $150 \mathrm{rpm} / \mathrm{min}$ within time 20, 45, 60, 75, and 90 minutes, respectively. Centrifugating with speed 2500 $\mathrm{rpm} / \mathrm{min}$ and determining remaining $\mathrm{Pb}^{2+}$ concentration by ICP-OES iCAP 6000 machine.

\subsubsection{Research on impact of $\mathrm{pH}$ on $\mathrm{Pb}^{2+}$ treatment efficiency}

Taking $100 \mathrm{~mL}$ of $10 \mathrm{mg} / \mathrm{L} \mathrm{Pb}^{2+}$ solution into 7 erlenmeyer flasks $(250 \mathrm{~mL})$ and turning to $\mathrm{pH}$ of $3,4,5,6,7,8$, and 9, respectively by $0.01 \mathrm{~N} \mathrm{HNO}_{3}$ and $\mathrm{NaOH}$. Adding $0.1 \mathrm{~g}$ nanosilica into each flask and shaking with speed $150 \mathrm{rpm} / \mathrm{min}$ within 60 minutes. Centrifugating with speed $2500 \mathrm{rpm} / \mathrm{min}$ and determining remaining $\mathrm{Pb}^{2+}$ concentration by ICP-OES iCAP 6000 machine.

\subsubsection{Research on impact of $\mathrm{Pb}^{2+}$ concentration on treatment efficiency by nanosilica}

Taking $100 \mathrm{~mL}$ deionized water into 8 erlenmeyer flasks $(250 \mathrm{~mL})$. Diluting $\mathrm{Pb}\left(\mathrm{NO}_{3}\right)_{2}$ to obtain $\mathrm{Pb}^{2+}$ solution with concentration of $5,10,15,20,25,30,35$, and $40 \mathrm{mg} / \mathrm{L}$, respectively then turning them to $\mathrm{pH}$ of 5 . Adding $0.1 \mathrm{~g}$ nanosilica into each flask and shaking with speed 150 $\mathrm{rpm} / \mathrm{min}$ within 60 minutes. Centrifugating with speed $2500 \mathrm{rpm} / \mathrm{min}$ and determining remaining $\mathrm{Pb}^{2+}$ concentration by ICP-OES iCAP 6000 machine. 


\subsubsection{Research on impact of nanosilica concentration on treatment efficiency by nanosilica}

Taking $10 \mathrm{mg} / \mathrm{L} \mathrm{Pb}^{2+}$ solution with $\mathrm{pH}$ of 5 into 6 erlenmeyer flasks $(250 \mathrm{~mL})$. Adding nanosilica in such a way that nanosilica concentration in each flask in a series of $0.1,0.5,1,1.5,2$ and $2.5 \mathrm{~g} / \mathrm{L}$. Shaking them with speed $150 \mathrm{rpm} / \mathrm{min}$ within 60 minutes. Centrifugating with speed $2500 \mathrm{rpm} / \mathrm{min}$ and determining remaining $\mathrm{Pb}^{2+}$ concentration by ICP-OES iCAP 6000 machine.

\section{Results and discussion}

\subsection{Characteristic of nanosilica extract from TEOS}

\subsubsection{Nanosilica extract composition}

XRD image (Figure 1) shows that nanosilica contains high $\mathrm{Si}$ content with mass percentage $99.2465 \%$ and molecular weight percentage $99.425 \%$. In addition, it also contains small amount of other elements such as $\mathrm{P}$ $(0.3329 \%), \mathrm{Ca}(0.4025 \%)$. It means the synthesized nanosilica is extremely pure and we can research and analyse material applications.

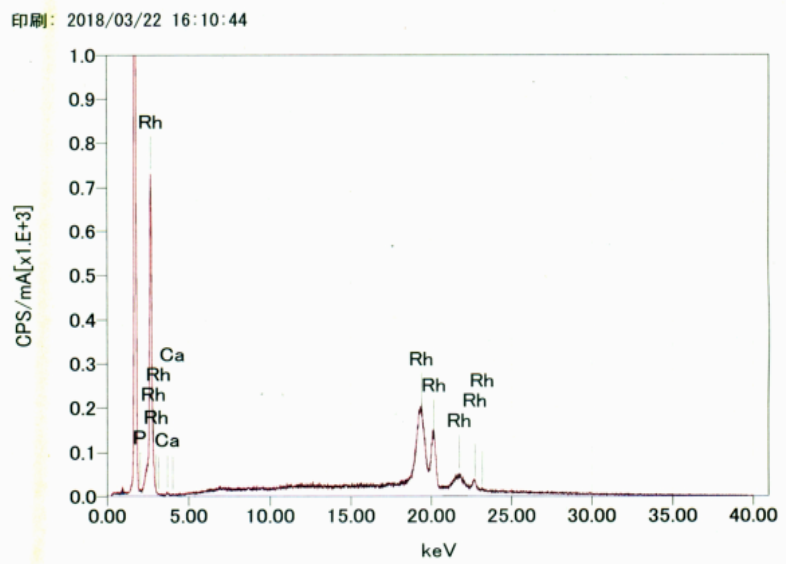

Figure 1. Energy-dispersive X-ray spectroscopy of nanosilica

\subsubsection{Nanosilica extract functional group}

The adsorption peak around $3250-3750 \mathrm{~cm}^{-1}$ indicates the existence of free hydroxyl groups. The vibration around $1634 \mathrm{~cm}^{-1}$ indicates the presence of $\mathrm{H}_{2} \mathrm{O}$. The peaks around $1105 \mathrm{~cm}^{-1}, 808 \mathrm{~cm}^{-1}$, and $470 \mathrm{~cm}^{-1}$ correspond to $\mathrm{Si}-\mathrm{O}$ and $\mathrm{Si}-\mathrm{O}-\mathrm{Si}$ stretching, respectively. Therefore, synthesized nanosilica is high purity.

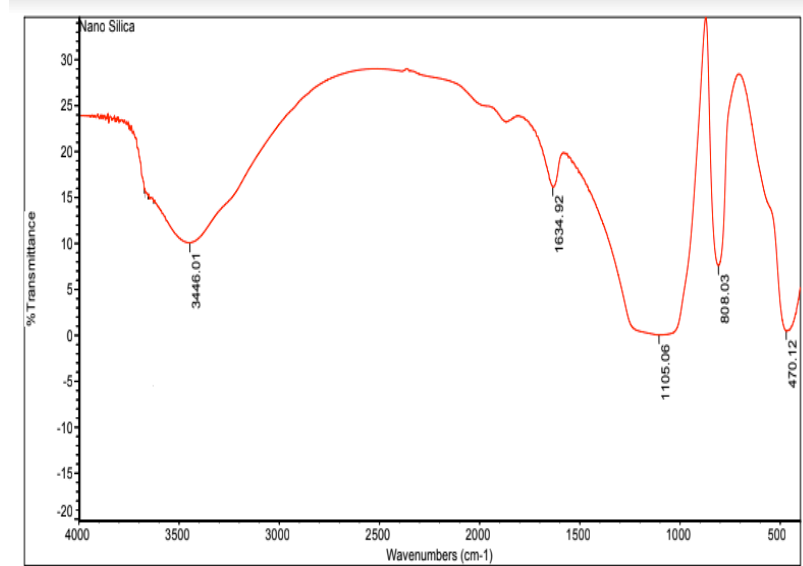

Figure 2. Fourier-transform infrared spectroscopygraph of nanosilica

\subsubsection{Nanosilica extract morphology and particle size}

Figure 3 presents nanosilica FESEM result by HATACHI S-4800 machine (Vietnam Academy of Science and Technology). It shows that nanosilica has average particle size about $60-100 \mathrm{~nm}$. With base catalyst $(\mathrm{pH}=8)$, TEOS hydrolytic reaction is easy to form $\mathrm{Si}(\mathrm{OH})_{4}$ because $\mathrm{OH}^{-}$ ion can infiltrate into $\mathrm{Si}$ atom immediately and replaces $\mathrm{OC}_{2} \mathrm{H}_{5}$ group of TEOS molecules. Thus, when $\equiv \mathrm{Si}(\mathrm{OH})$ precipitated, silica gel groups have a preferential branching structure for all sides, the result is the nanosilica material is usually spherical, as shown in Figure 3.

The particles distinguish clearly which do not have adhesion together, disperse uniformly to make large surface area and wide contact area. It leads to high adsorption ability and high polluted treatment efficiency. Comparing with nano particles (Thai Hoang at el., 2012) showed that the particles in this report distribute better and distinguishable clearly.

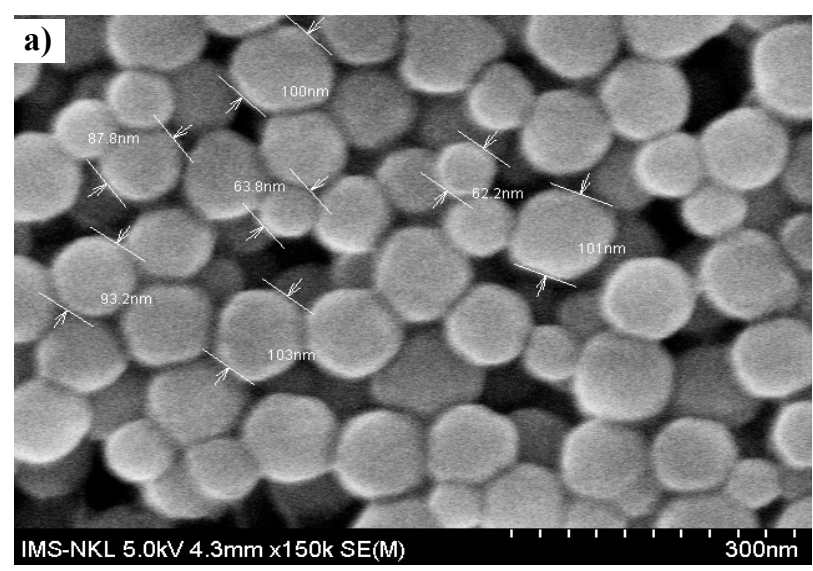



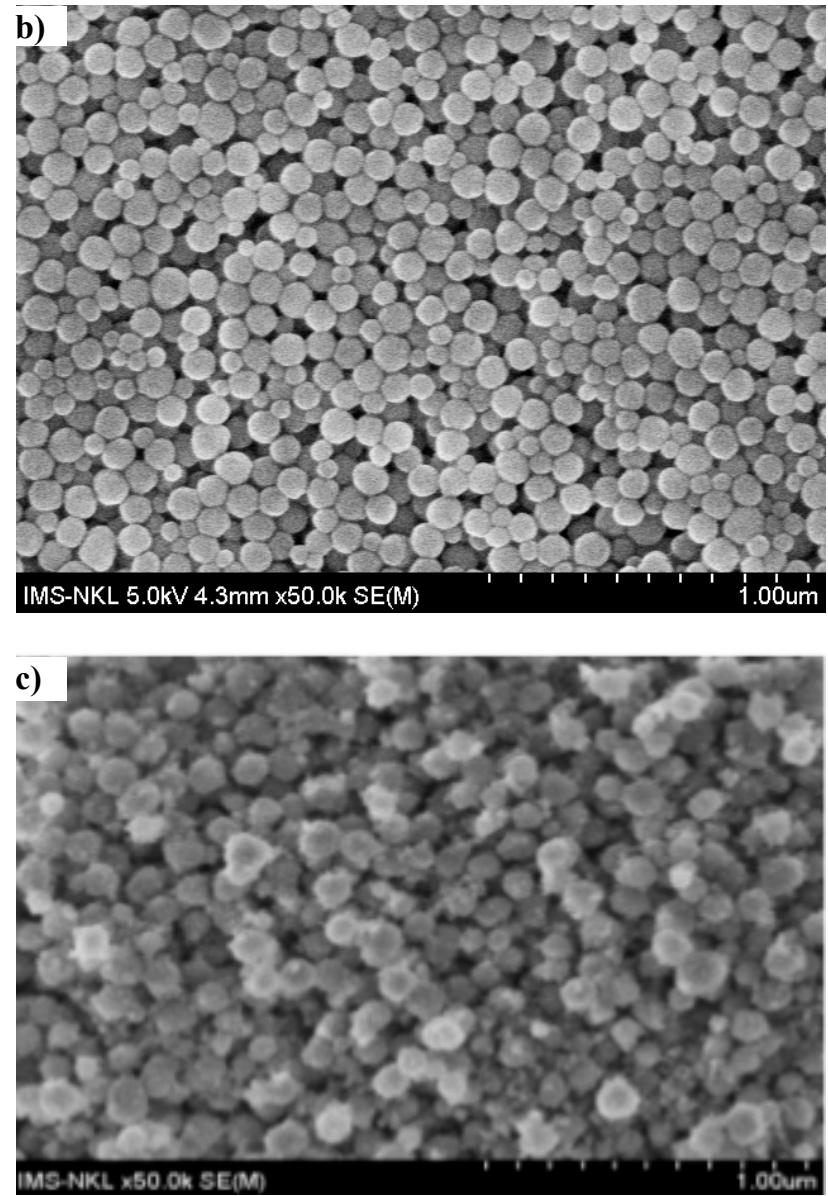

Figure 1. a, b) Field emission scanning electron micrograph (FESEM) of Nanosilica at different resolution scale; c) FESEM of Nanosilica (Thai Hoang at el., 2012)

\subsubsection{Nanosilica extract structure}

Nanosilica X-ray diffraction pattern shown in Figure. 7 shows that the major component of this material is high purity nanosilica, which is not confused by other impurities. Comparing with X-ray diffraction pattern of nanosilica obtained from the study of nanosilica's XRD (Xuejing Chen at el., 2014), it only appears one wide peak at $2 \theta=$ $22.5^{\circ}$, which indicates that nanosilica particles have small particle size and weak intensity, form in amorphous, crystal clear. Compared with crystalline silica, amorphous silica has more advantages such as non-toxic and better interaction and polluted absorbent (Xuejing Chen et al., 2014)

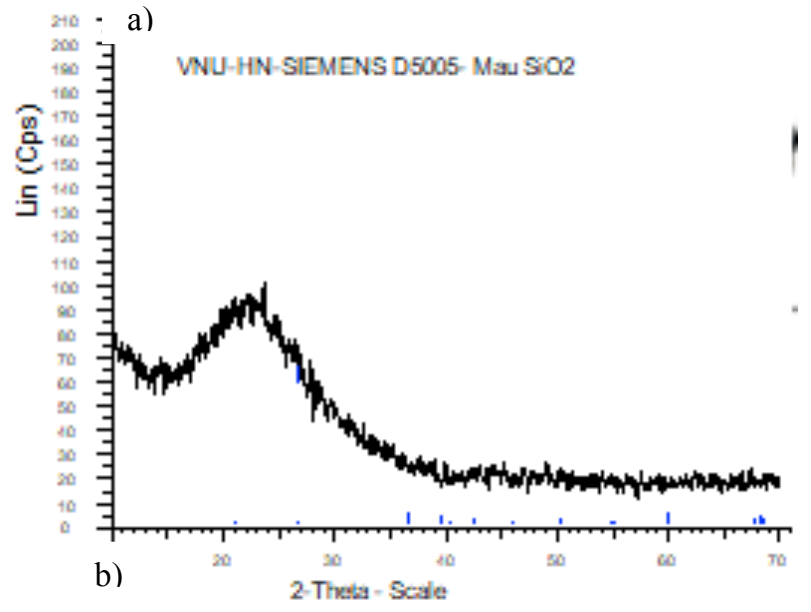

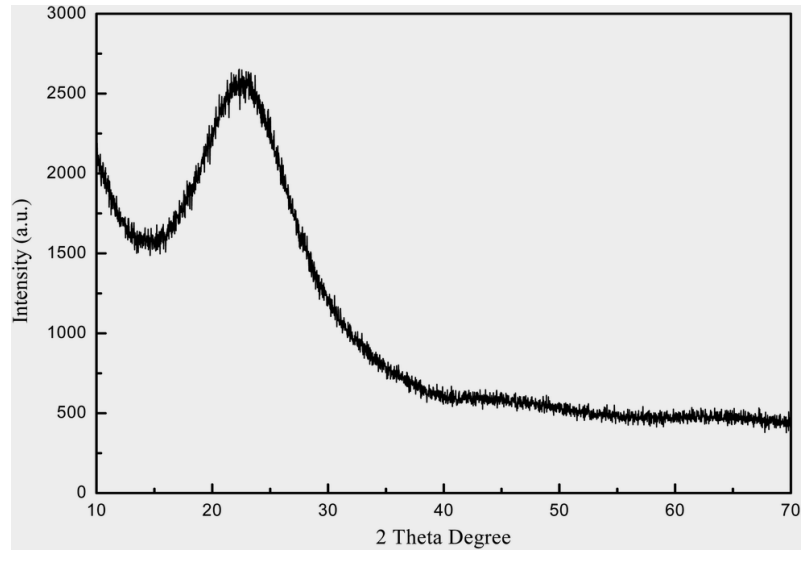

Figure 4. a) X-ray diffraction pattern of Nanosilica; b) X-ray diffraction pattern of Nanoslica (Xuejing Chen et al., 2014)

\section{2. $\mathbf{P b}^{2+}$ treatment efficiency of nanosilica at different conditions}

\subsubsection{Impact of treatment time on $\mathrm{Pb}^{2+}$ treatment efficiency}

$\mathrm{Pb}^{2+}$ treatment result of $0.1 \mathrm{~g}$ nanosilica in different duration of time, with the $\mathrm{pH}$ of 5 and initial concentration 10 $\mathrm{mgPb}^{2+} / \mathrm{L}$ is represented in Figure 5 .

At first 20 minutes after treating, the efficiency raises quickly and reaches to $90.97 \%$. The longer time the higher treatment efficiency, it gets $96.17 \%$ after 60 minutes and remaining $\mathrm{Pb}^{2+}$ concentration is $0.383 \mathrm{mgPb}^{2+} / \mathrm{L}$. After 90 minutes, almost $\mathrm{Pb}^{2+}$ is adsorbed completely and and remaining $\mathrm{Pb}^{2+}$ concentration is $0.002 \mathrm{mgPb}^{2+} / \mathrm{L}$. Thus, the range of time from 60 to 90 minutes is the optimal condition to carry out the next experiments.

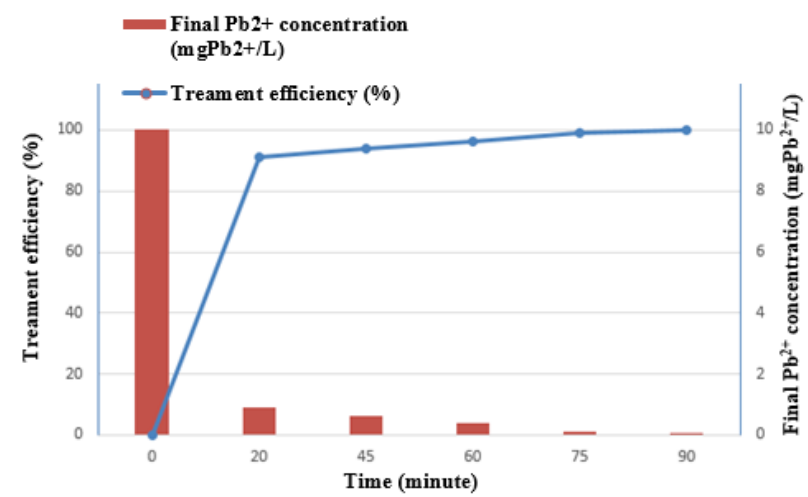

Figure 5. $\mathrm{Pb}^{2+}$ concentration and efficiency treatment at different time

\subsubsection{Impact of $\mathrm{pH}$ on $\mathrm{Pb}^{2+}$ treatment efficiency}

$\mathrm{Pb}^{2+}$ treatment result of $0.1 \mathrm{~g}$ nanosilica at different $\mathrm{pH}$, initial concentration $10 \mathrm{mgPb}^{2+} / \mathrm{L}$, and shaking within 60 minutes is represented in Figure 6. 


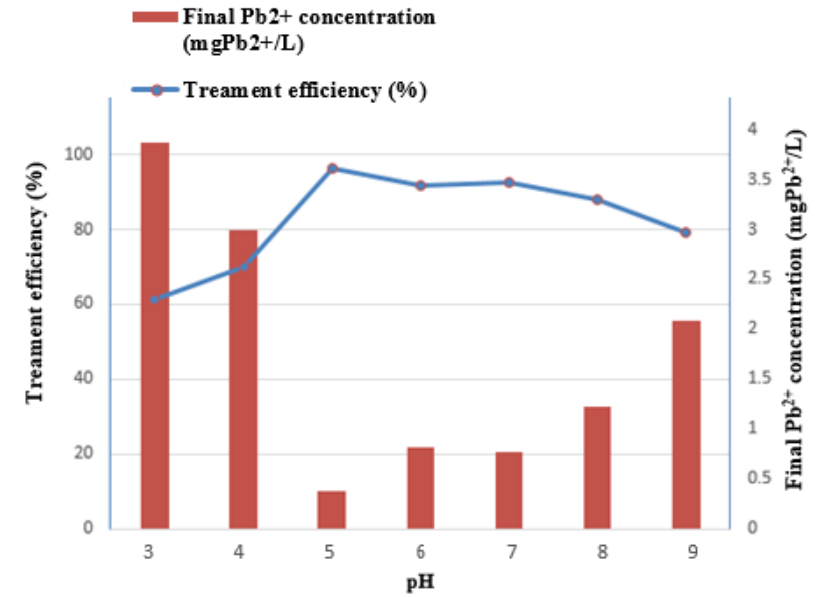

Figure 6. $\mathrm{Pb}^{2+}$ concentration and efficiency treatment at different $\mathrm{pH}$

The result shows that lead $\left(\mathrm{Pb}^{2+}\right)$ treatment efficiency raises when $\mathrm{pH}$ increases form 3 to 5 . At $\mathrm{pH}=5$, the treatment efficiency is highest (approximately 96.17\%), the remainning lead in solution is $0.383 \mathrm{mg} \mathrm{Pb}^{2+} / \mathrm{L}$. According to Ahmed and RAM (1992), hydroxyl groups on $\mathrm{SiO}_{2}$ exist at acid- base balance such as:

$$
\begin{gathered}
>\mathrm{SiOH}_{2}{ }^{+} \stackrel{\text { pKa } 1}{\leftrightarrow}>\mathrm{SiOH}+\mathrm{H}^{+}(1) \\
>\mathrm{SiOH} \stackrel{\text { pKa2 }}{\leftrightarrow}>\mathrm{SiO}^{-}+\mathrm{H}^{+}(2)
\end{gathered}
$$

From reaction (1) and (2), it indicates that when $\mathrm{pH}$ raises, the balance move following increasing negative charge tendency on $\mathrm{SiO}_{2}\left(>\mathrm{SiO}^{-}\right)$surface. It causes a strong electrostatic attraction between the positive lead-adsorbed material $\left(\mathrm{Pb}^{2+}\right)$ and the negative charge of $\mathrm{SiO}_{2}$ adsorbent so the capacity and adsorption efficiency increase. In contrast, when $\mathrm{pH}$ decreases, balance will move following increasing positive charge on $\mathrm{SiO}_{2}\left(>\mathrm{SiOH}_{2}{ }^{+}\right)$and make capacity and adsorption efficiency decrease (Ahmed M. N. and R. N. Ram., 1992). When $\mathrm{pH}$ is in range of 5 to 7 , treatment efficiency is negligible change. At $\mathrm{pH}=7$, the efficiency reaches $92.34 \%$. When $\mathrm{pH}$ is larger than 7 , the high $\mathrm{OH}^{-}$ion concentration leads to react slowly.

$$
\mathrm{SiO}_{2}+2 \mathrm{OH}^{-} \rightarrow \mathrm{SiO}_{3}{ }^{2-}+\mathrm{H}_{2} \mathrm{O}
$$

Absorbed ability of $\mathrm{SiO}_{3}{ }^{2-}$ ion is lower than nanosilica $\left(\mathrm{SiO}_{2}\right) . \mathrm{SiO}_{3}{ }^{2-}$ ion making lead treament ability of material decreases. Thus, when $\mathrm{pH}$ is larger than 8 , the efficiency begins decreasing.

\subsubsection{Impact of initial $\mathbf{P b}^{2+}$ concentration on $\mathbf{P b}^{2+}$ treatment efficiency}

$\mathrm{Pb}^{2+}$ treatment result of $0.1 \mathrm{~g}$ nanosilica at different $\mathrm{Pb}^{2+}$

\begin{tabular}{|c|c|c|c|c|}
\hline $\begin{array}{c}\text { Initial } \mathrm{Pb}^{2+} \text { concentration } \\
(\mathrm{mg} / \mathrm{L})\end{array}$ & $\begin{array}{c}\text { Final } \mathrm{Pb}^{2+} \\
\text { concentration }(\mathrm{mg} / \mathrm{L})\end{array}$ & $\begin{array}{c}\text { Treated } \mathrm{Pb}^{2+} \\
\text { concentration } \mathrm{Q}_{\mathrm{e}}(\mathrm{mg} / \mathrm{g})\end{array}$ & $\begin{array}{l}\mathrm{C}_{\mathrm{e}} / \mathbf{Q}_{\mathrm{e}} \\
(\mathrm{g} / \mathrm{L})\end{array}$ & $\begin{array}{l}\mathrm{Pb}^{2+} \text { treatment } \\
\text { efficiency }(\%)\end{array}$ \\
\hline 5 & 0.173 & 4.827 & 0.036 & 96.54 \\
\hline 10 & 0.383 & 9.617 & 0.040 & 96.17 \\
\hline 15 & 1.196 & 13.804 & 0.087 & 92.03 \\
\hline 20 & 2.141 & 17.859 & 0.120 & 89.30 \\
\hline 25 & 3.537 & 21.463 & 0.165 & 85.85 \\
\hline 30 & 5.462 & 24.538 & 0.223 & 81.80 \\
\hline 35 & 8.011 & 26.989 & 0.297 & 77.11 \\
\hline 40 & 12.452 & 27.548 & 0.452 & 68.67 \\
\hline QCVN 40:2011 & 0.5 & - & - & - \\
\hline
\end{tabular}
concentrations, the $\mathrm{pH}$ of 5 , and shaking within 60 minutes is represented in Table 1 .

Table 1. $\mathrm{Pb}^{2+}$ concentration after treatment and setting up Langmuir's adsorptive isotherm equation

The Langmuir's adsorptive isotherm equation:

$$
Q e=Q_{\max } \frac{b \cdot C_{e}}{1+b \cdot C_{e}}(*)
$$

Where:

$\mathrm{C}_{\mathrm{e}}$ - equilibrium concentration of adsorbed substance $(\mathrm{mg} / \mathrm{L})$;

$\mathrm{Q}_{\mathrm{e}}$ - adsorptive capacity $(\mathrm{mg} / \mathrm{g})$;

$\mathrm{Q}_{\max }$ - maximum adsorptive capacity calculated by theory $(\mathrm{mg} / \mathrm{g})$;

b - Langmuir equations coefficients (determined from experiments).

To determine the constants in the Langmuir's isotherm equation, the graph method converting equation (*) into linear equation, in which $C_{e} / Q_{e}$ depends on first order of $\mathrm{C}_{\mathrm{e}}$ as the following:

$$
\frac{C e}{Q e}=\frac{1}{Q \max } \cdot C e+\frac{1}{b \cdot Q \max }\left({ }^{* *}\right)
$$

Depending on Langmuir model, maximum adsorption concentration $\mathrm{Qmax}=30.3 \mathrm{mg} / \mathrm{g}$, and adsorbent and adsorbate constant $b=0.868 \mathrm{~L} / \mathrm{g}$.

As a result, treatment efficiency reduces when initial $\mathrm{Pb}^{2+}$ concentration raises because nanosilica surface is occupied fully by lead molecule when adsorption system reaches equilibrium. With nanosilica concentration $1 \mathrm{~g} / \mathrm{L}$, treatment time 60 minutes, the $\mathrm{pH}$ of 5 and initial $\mathrm{Pb}^{2+}$ concentration $\leq 10 \mathrm{mg} / \mathrm{L}, \mathrm{Pb}^{2+}$ concentration after treatment fit for QCVN 40:2011/BTNMT (column B)- National Technical Regulation on Industrial Wastewate 
(column B: values are applied for industrial wastewater discharged into urban drainage systems, residential areas without centralized waste water treatment plants).

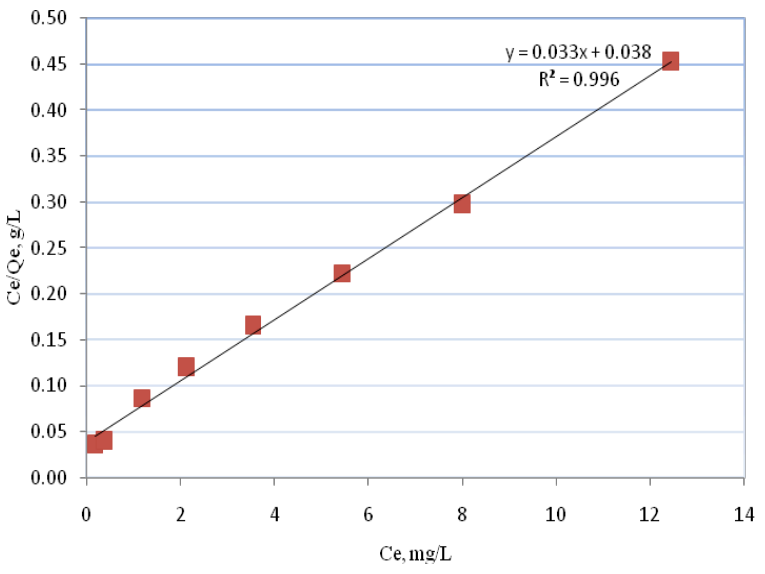

Figure 7. The Langmuir's adsorptive isotherm equation on lead removal by nanosilica

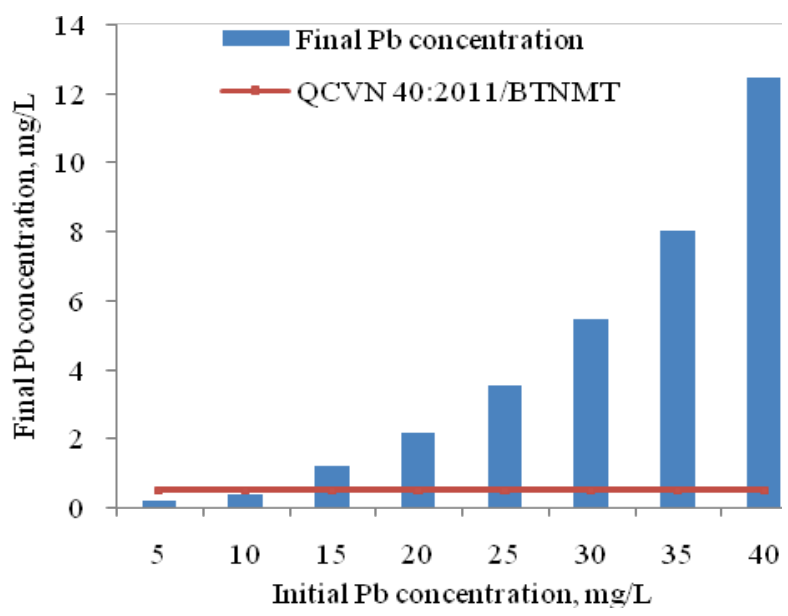

Figure 8 . $\mathrm{Pb}^{2+}$ treatment efficiency with different initial $\mathrm{Pb}^{2+}$ concentrations

\subsubsection{Impact of nanosilica concentrations on $\mathbf{P b}^{2+}$ treatment efficiency}

$\mathrm{Pb}^{2+}$ treatment result of different nanosilica concentrations at initial concentration $10 \mathrm{mgPb}^{2+} / \mathrm{L}$, the $\mathrm{pH}$ of 5 , and shaking within 60 minutes is represented in Figure 9.

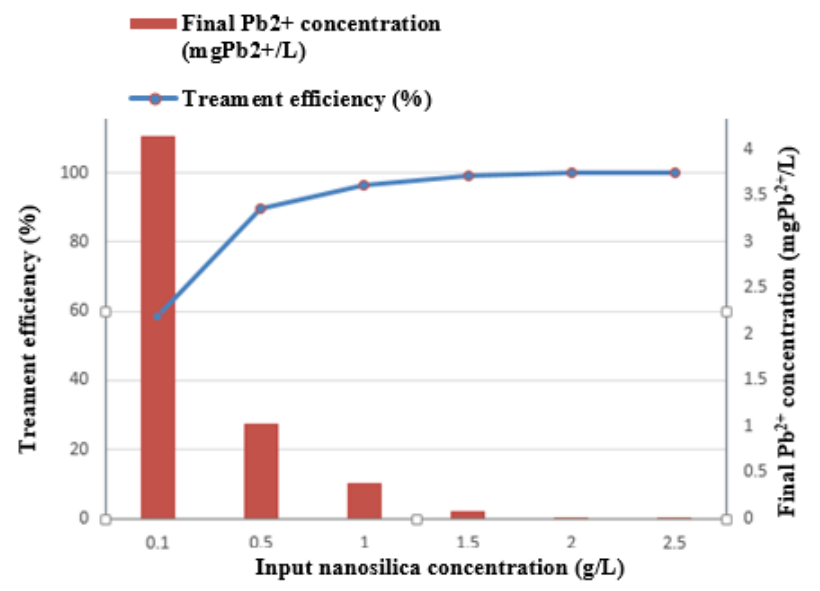

Figure 9. $\mathrm{Pb}^{2+}$ treatment efficiency of nanosilica at different input concentrations

Figure 9 shows that treatment efficiency grows up after adding nanosilica. When nanosilica concentration reaches $1 \mathrm{~g} / \mathrm{L}$, almost $\mathrm{Pb}^{2+}$ concentration is removed at efficiency $96.17 \%$, and $\mathrm{Pb}^{2+}$ remaining concentration is 0.383 $\mathrm{mgPb}^{2+} / \mathrm{L}$. Nanosilica concentration in the range of $1-2.5$ $\mathrm{g} / \mathrm{L}$ leads to negligible change in $\mathrm{Pb}^{2+}$ treatment efficiency.

\subsection{Nanosilica synthesis from rice husk}

At present, nanoscale silica materials are prepared using several methods, including vapor-phase reaction, sol-gel and thermal decomposition technique. However, their high cost of preparation has limited their wide application. In contrast, rice husk ( $\mathrm{RH})$ is an agricultural waste whose major constituents are organic materials and hydrated silicon. Because the silicon atoms in the rice husk have been naturally and uniformly dispersed by molecular units, very fine particle size, with very high purity and surface area silica powder can be prepared under controlled conditions. In addition, the reaction can occur easier than the conventional experimental technique. This process has the benefit not only of producing valuable silica powder but also of reducing disposal and pollution problems.

Precipitation of silica- chemical reaction involved (Tzong-Horng Liou, Chun-Chen Yang., 2011 and U. Kalapathy et al., 2000):

$$
\begin{gathered}
\mathrm{SiO}_{2}+2 \mathrm{NaOH} \rightarrow \mathrm{Na}_{2} \mathrm{SiO}_{3}+\mathrm{H}_{2} \mathrm{O} \\
\mathrm{Na}_{2} \mathrm{SiO}_{3}+\mathrm{H}_{2} \mathrm{SO}_{4} \rightarrow \mathrm{SiO}_{2}+\mathrm{Na}_{2} \mathrm{SO}_{4}+\mathrm{H}_{2} \mathrm{O}
\end{gathered}
$$

Nanosilica is synthesized by sol-gel method with 4 main steps:

Washing and dry: Rice husk was washed thoroughly with water to remove the soluble particles, dust, and other contaminants present, whereby the heavy impurities such as sand are also removed. It was then dried in an air oven at about $110^{\circ} \mathrm{C}$ for $24 \mathrm{~h}$.

Acid treatment: An acid washing step was used to remove the small quantities of minerals prior to silica extraction 
from rice husk ash (RHA). Ten grams of RHA samples were dispersed in $60 \mathrm{ml}$ of $\mathrm{HCl} 1 \mathrm{~N}$.

Thermal treatment: A weighed $\mathrm{RH}$ as well as $\mathrm{RH}$ were subjected to heat treatment to obtain the ash. Samples were burned inside a programmable furnace (Nabertherm controller B 170, Nabertherm GmbH, Lilienthal, Germany) at different temperatures $\left(500,700\right.$, and $\left.1000^{\circ} \mathrm{C}\right)$ and optimal temperature $700^{\circ} \mathrm{C}$ in $6 \mathrm{~h}$.

Silica extraction: A sample of $2.5 \mathrm{~g}$ RHA was stirred in a $250 \mathrm{~mL}, 0.5 \mathrm{M}$ sodium hydroxide solution. The solution was heated in a covered beaker by stirring constantly and was allowed to stand at room temperature then filtered Nanosilica preparation: $\mathrm{HCl}$ was added until neutralized. The precipitate silica was washed repeatedly with warm, deionized water and then was centrifugated with speed $5000 \mathrm{rpm}$ within $10 \mathrm{mins}$ repeated in 3 times. The product is dried at $110^{\circ} \mathrm{C}$ for $24 \mathrm{~h}$ in the oven and crystallization in a programmable furnace at $450^{\circ} \mathrm{C}$ in $1 \mathrm{~h}$. Then crushed them to collect nanosilica.

\section{Nanosilica extract composition}

EDX elemental spectra of rice husk showed major element silicon ( $\mathrm{Si}$ ) and impurities Rhodium $(\mathrm{Rh})$, lead $(\mathrm{Pb})$, iron (Fe) and Arsenic (As). Silica content of the xerogels was estimated from the EDX data based on the assumption that all of the silicon was in the form of silica. The silica content of xerogels produced from washed $\mathrm{RH}$ were $99.5 \%$. It is interesting to note that impurity elements were also present in a lower concentration even detected in the nanosilica. The color of nanosilica was white after synthesis.

\section{Nanosilica extract functional group}

FTIR spectroscopy was used to detect the presence of functional groups in the silica nanoparticle (SNPs). The major chemical groups present in silica are identified by the FTIR spectra shown in Figure 5. Six functional groups are found in samples: hydroxyl groups, C-H stretching, $\mathrm{C}=\mathrm{C}$ stretching, $\mathrm{Si}-\mathrm{O}-\mathrm{Si}$ stretching, $\mathrm{Si}-\mathrm{H}$ groups, and $\mathrm{OCH}_{3}$ stretching.

The adsorption peak around $3447.27 \mathrm{~cm}^{-1}$ indicates the existence of free hydroxyl groups. In rice husk, the $\mathrm{C}-\mathrm{H}$ stretching vibration around $2924.02 \mathrm{~cm}^{-1}$ indicates the presence of alkane functional group. The $\mathrm{C}=\mathrm{C}$ stretching vibrations between 1636.44-1653.91 $\mathrm{cm}^{-1}$ indicates alkenes and aromatic functional groups. The peaks around $1077.8-1097.58 \mathrm{~cm}^{-1}, 800.12 \mathrm{~cm}^{-1}$, and 466.76- 470.37 $\mathrm{cm}^{-1}$ correspond to $\mathrm{Si}-\mathrm{O}-\mathrm{Si}$ stretching, $\mathrm{Si}-\mathrm{H}$ groups, $\mathrm{OCH}_{3}$ stretching, respectively. The presence of polar groups on the surface is likely to provide the considerable cation exchange capacity to the adsorbent.

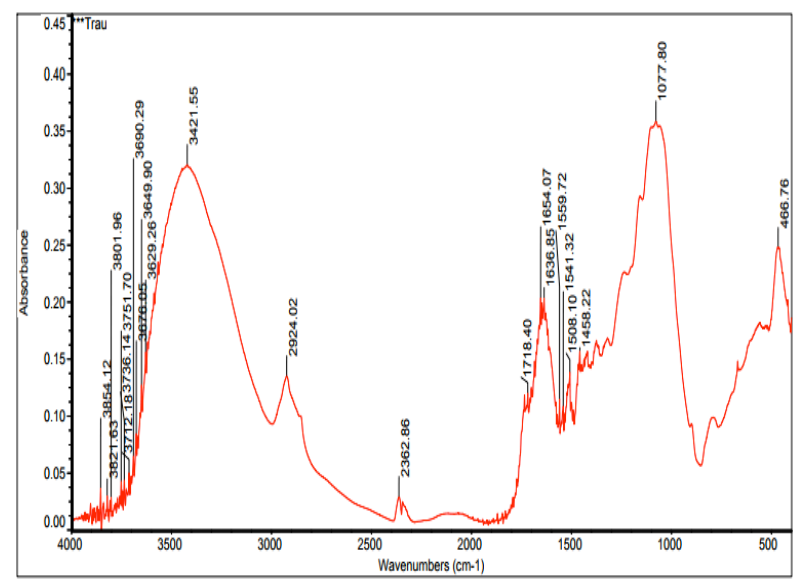

a)

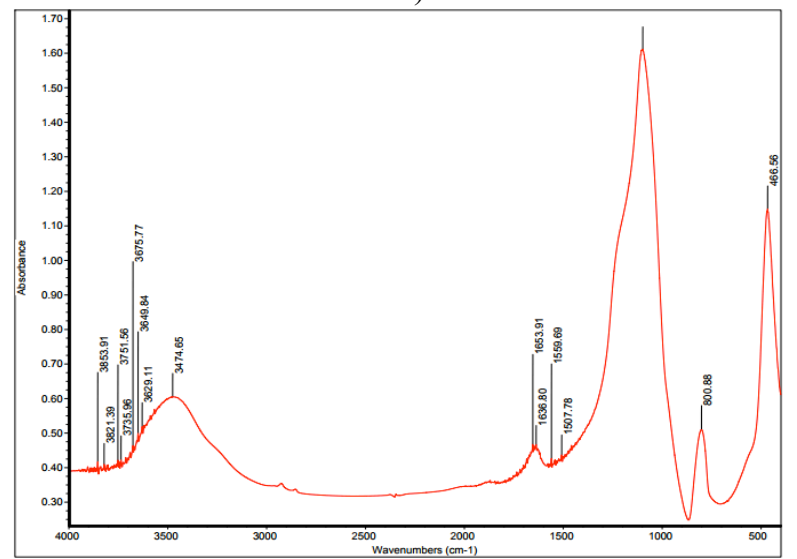

b)

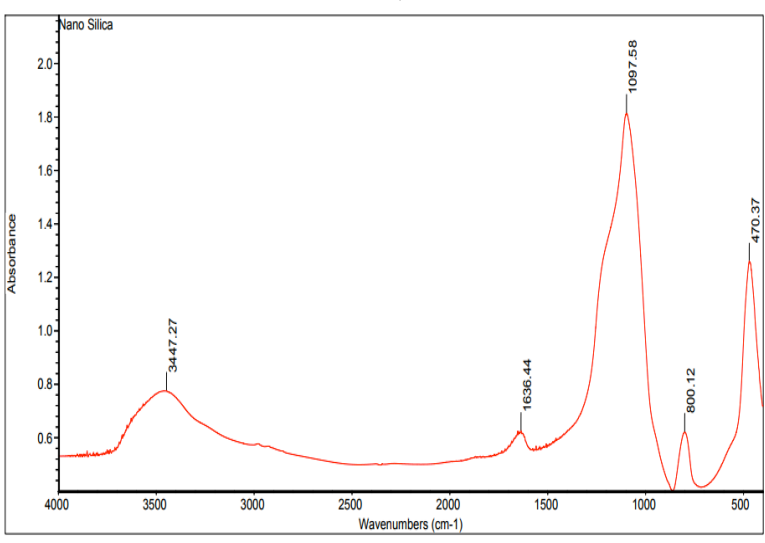

c)

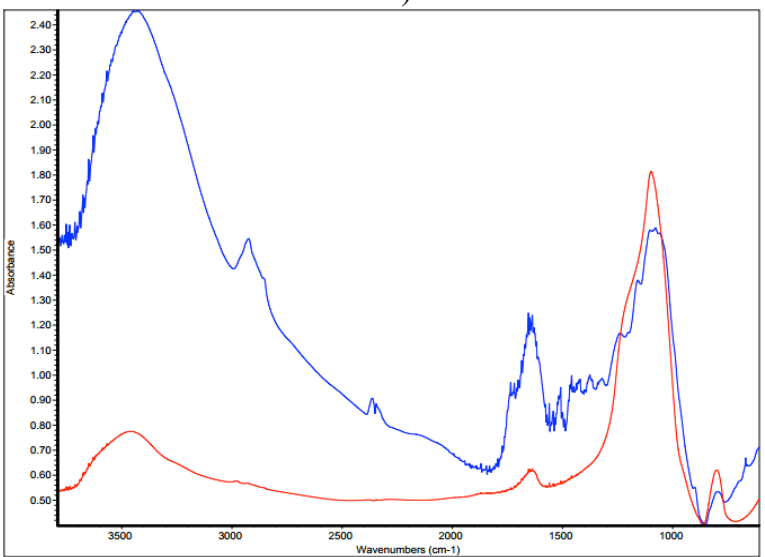

d)

Figure 10. Fourier-transform infrared spectroscopygraph of a) rice husk, b) rice husk ash, c) nanosilica from rice husk d) compararison a and $c$ 
Compared to rice husk, synthesized nanosilica resulted in a loss of $\mathrm{C}-\mathrm{H}$ stretching band and a addition of Si-H. These were decreased in the primary functional groups of $\mathrm{OH}$ and $\mathrm{C}=\mathrm{C}$ and increased in silica functional groups of Si-O-Si.

\section{Nanosilica extract morphology and particle size}

Figure 11 illustrates the SEM images of SNPs samples. It presented that synthesized nanosilica have spongy structure. Particle size and morphology of synthesized silica were examined by FESEM with high enlargement. It can be observed that SNPs have a circular shape with average particle size of $30-100 \mathrm{~nm}$.

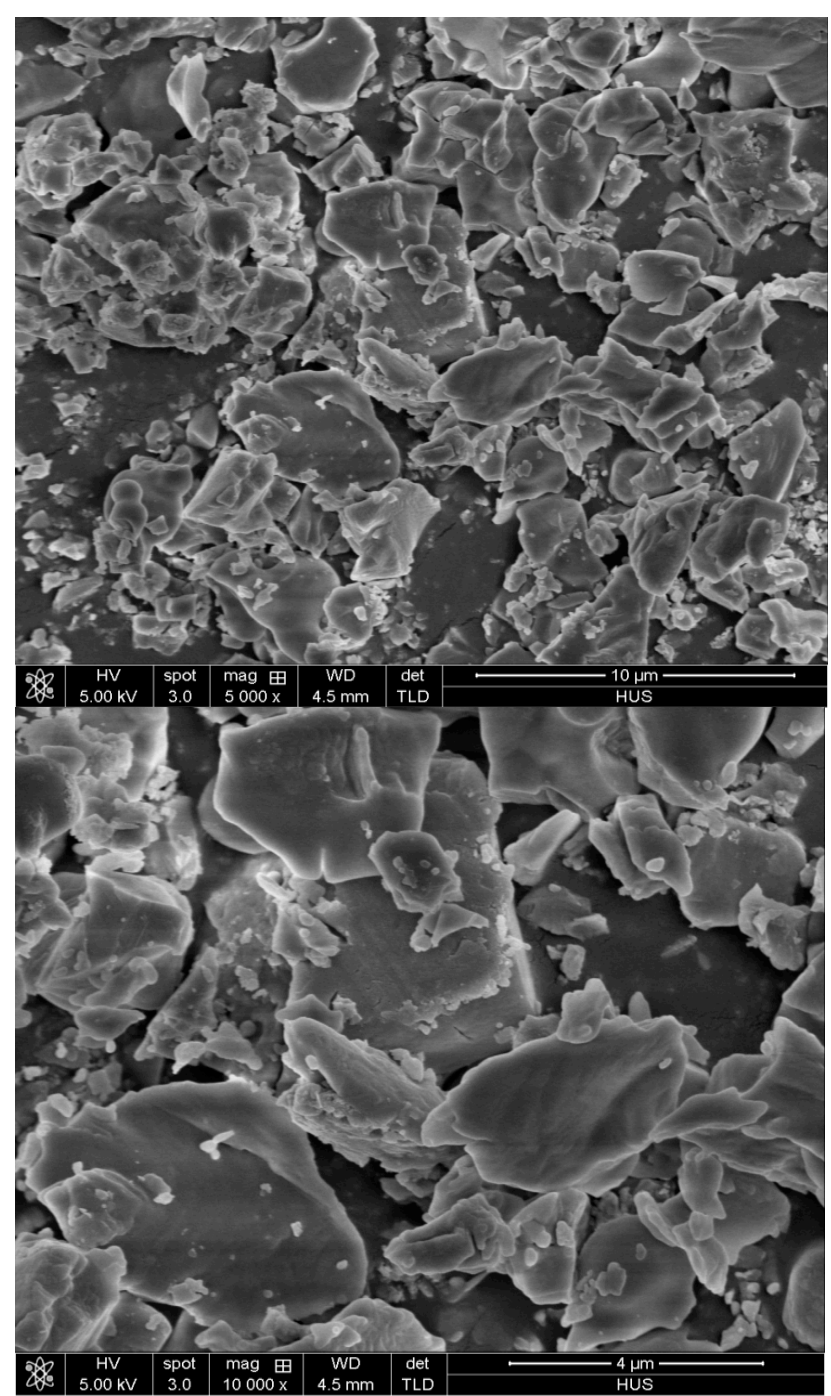

Figure 11. Scanning electron micrograph (SEM) of nanosilica from rice husk

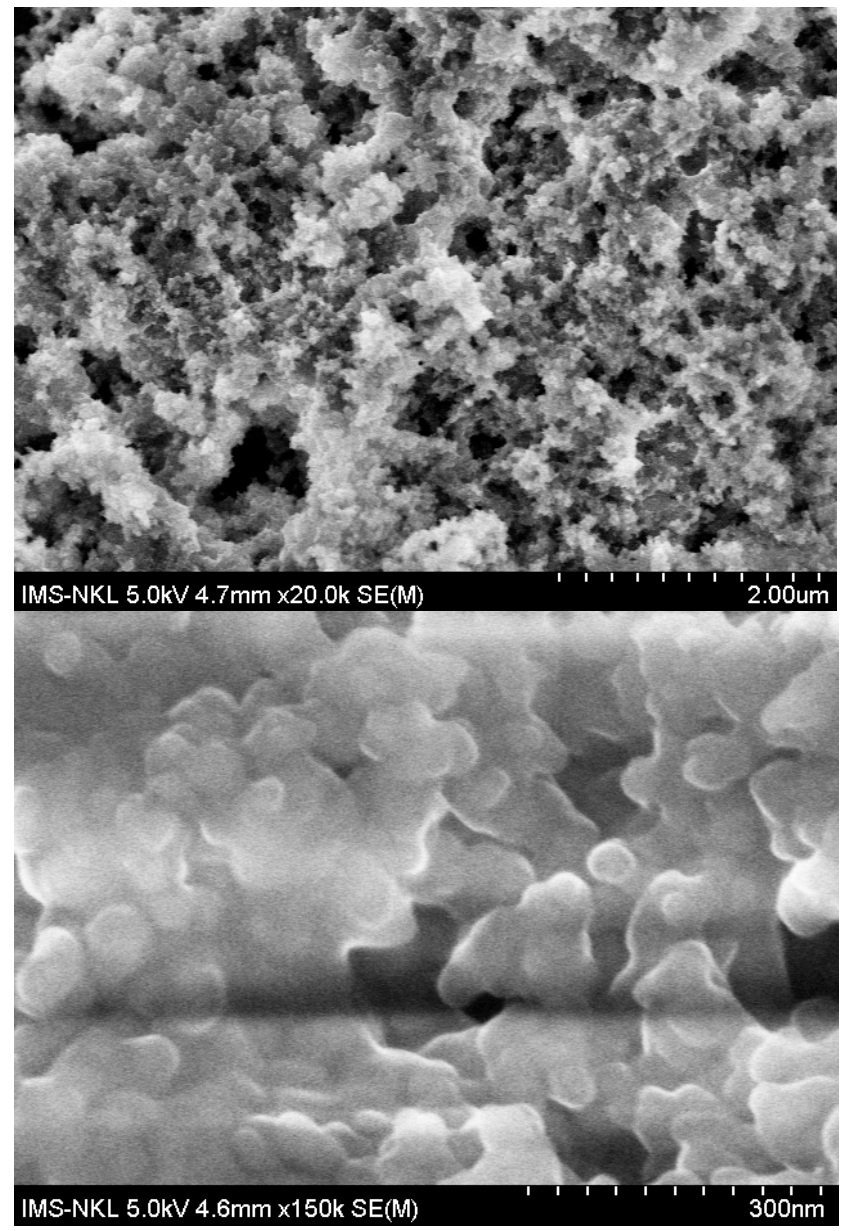

Figure 12. Field emission scanning electron micrograph (FESEM) of nanosilica from rice husk

\section{Nanosilica extract structure}

X-ray diffraction pattern of extracted silica is presented in Figure 13. Hill like peak in the range of $[2 \theta]=21$ to 24 , indicates the absence of any ordered crystalline structure and highly disordered structure of silica and extracted nanosilica is purity.

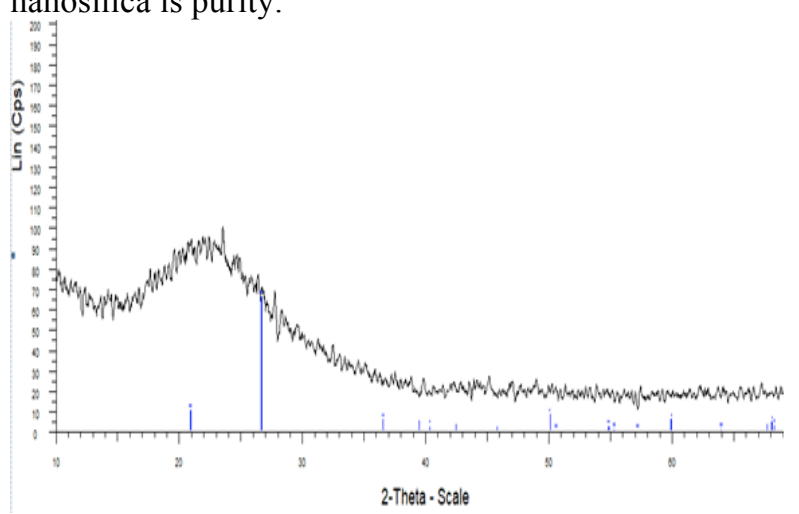

Figure 13. X-ray diffraction pattern of nanosilica

\section{Conclusion}

Purity nanosilica $(60-100 \mathrm{~nm})$ is synthesized by sol-gel method from TEOS with base catalysts and volumetric ratio TEOS $/ \mathrm{C}_{2} \mathrm{H}_{5} \mathrm{OH} / \mathrm{H}_{2} \mathrm{O} / \mathrm{NH}_{4} \mathrm{OH}$ : 5/30/1/1 and can be applied efficiency to treat lead in water. $\mathrm{Pb}^{2+}$ treatment efficiency increases following time, accelerates within first 20 minutes and then raises slowly and the highest 
efficiency is $96.17 \%$ after 60 minutes. It increases in the range of $\mathrm{pH} 3-5$. The highest is $96.17 \%$ at the $\mathrm{pH}$ of 5 and the remaining concentration is $0.383 \mathrm{mgPb}^{2+} / \mathrm{L}$. When $\mathrm{pH}$ is larger than 8 , the efficiency starts decreasing. As a resut, maximum adsorption concentration $\mathrm{Qmax}=30.3$ $\mathrm{mg} / \mathrm{g}$, and adsorbent and adsorbate constant $\mathrm{b}=0.868$ $\mathrm{L} / \mathrm{g}$. The higher nanosilica concentration seems being adsorbed completely. In addition, nanosilica also can be synthesized from rice husk with similar characteristics such as particle size $30-100 \mathrm{~nm}$, spongy structure, and clean material and has orientation to apply to treat lead in water in future research.

\section{References}

[1] Ahmed M. N. and R. N. Ram (1992) Removal of basic dye from waste-water using silica as adsorbent. Environmental Pollution 77, 79-86.

[2] Enrique C. Peresa, Jenifer C. Slaviero, Anaelise M. Cunha, Ahmad Hosseini-Bandegharaei,Guilherme L. Dotto (2017) Microwave synthesis of silica nanoparticles and its application for methylene blue adsorption. Journal of Environmental Chemical Engineering 6(1), 649-659.

[3] Ezzat Rafiee1, Shabnam Shahebrahimi, Mostafa Feyziand Mahdi Shaterzadeh (2012) Optimization of synthesis and characterization of nanosilica produced from rice husk (a common waste material). International Nano Letters 2(1), 29.

[4] Farshid Ghorbani1, Ali Mohammad Sanati 2, Maryam Maleki 3 (2015) Production of Silica Nanoparticles from Rice Husk as Agricultural Waste by Environmental Friendly Technique. Environmental Studies of Persian Gulf 2(1), 56-65.

[5] Thai Hoang, Nguyen Thuy Chinh, Nguyen Thi Thu Trang, Vu Quoc Manh (2012), Synthesized nanosilica and nanocomposite eva/silica material using evagma compatibilizer. Journal of Chemistry, 50.

[6] Ilka Gehrke, Andreas Geiser, and Annette SombornSchulz (2015) Innovations in nanotechnology for water treatment. Nanotechnol Sci Appl 8, 1-17.

[7] Lu, P. and Y.-L. Hsieh (2012). Highly pure amorphous silica nano-disks from rice straw. Powder Technology 225, 149-155.

[8] Paul B Tchounwou, Clement G Yedjou, Anita K
Patlolla, and Dwayne J Sutton (2014) Heavy metals toxicity and the Environment. Molecular, Clinical and Environmental Toxicology, Part of the Experientia Supplementum book series (EXS, volume 101), pp. 133-164. HHS public Access. doi: 10.1007/978-3-7643-8340-4_6.

[9] QCVN 40:2011/BTNMT (B): National Technical Regulation on Industrial Wastewater (column B: values are applied for industrial wastewater discharged into urban drainage systems, residential areas without centralized waste water treatment plants).

[10] Rahele Rostamian, Mojgan Najafi, Amir Abbas Rafati (2011) Synthesis and characterization of thiolfunctionalized silica nano hollow sphere as a novel adsorbent for removal of poisonous heavy metal ions from water: Kinetics, isotherms and error analysis. Chemical Engineering Journal 171, 1004-1011.

[11] Rajesh Ghosh and Sounak Bhattacherjee (2013) A Review Study on Precipitated Silica and Activated Carbon from Rice Husk. Chemical Engineering \& Process Technology. 4(4), 156.

[12] Sang-Bae Jung, Jung-Ho Kim, Hong-Ryul Kim, Hyung-Ho Park (2003), E ffect of solvent on the preparation of ambient pressure-dried $\mathrm{SiO} 2$ aerogel films, Microelectronic Engineering 65, 113-122.

[13] Tzong-Horng Liou, Chun-Chen Yang (2011) Synthesis and surface characteristics of nanosilica produced from alkali-extracted rice husk ash. Materials Science and Engineering. B 176, 521-529.

[14] Tahereh Gholami, Masoud Salavati-Niasari, Mehdi Bazarganipour (2013), Elham Noori Synthesis and characterization of spherical silica nanoparticles by modified Stöber process assisted by organic ligand, Superlattices and Microstructures 61, 33-41.

[15] U. Kalapathy a, A. Proctor a, J. Shultz b (2000) A simple method for production of pure silica from rice hull ash . Bioresource Technology 73, 257-262.

[16] Van Hai Le, Chi Nhan Ha Thuc and Huy Ha Thuc (2013) Synthesis of silica nanoparticles from Vietnamese rice husk by sol-gel method. Nanoscale Reseach Letters 8, 58.

[17] Xuejing Chen, Jianguo Jiang, Feng Yan, Sicong Tiana and Kaimin Lia (2014) A novel low temperature vapor phase hydrolysis method for the production of nano-structured silica materials using silicon tetrachloride. RSC Adv. 4, 8703-8710. 